\title{
Nursing interventions in the management program for chronic patients: cross mapping
}

\author{
Intervenções de Enfermagem no programa de gerenciamento de crônicos: mapeamento \\ cruzado
}

\section{Intervenciones de Enfermería en el programa de gestión de crónicos: mapeo cruzado}

Talita do Nascimento da Silva ${ }^{1}$, Rosimere Ferreira Santana ${ }^{1}$, George Luiz Alves Santos ${ }^{1}$, Luana de França da Silva ${ }^{1}$, Giselle Mota Bastos ${ }^{1}$, Thaís Diniz Garcia²

One aimed to analyze nursing interventions in the medical records of the elderly assisted by the management program for chronic patients, comparing them with the Nursing Interventions Classification. The investigation was carried out in a private health service in Rio de Janeiro, Brazil, in March 2014. This is a cross mapping study, with a quantitative approach. The sample was composed of 80 medical records according to the following criteria: attended in 2013; average complexity II; age over 64 years old; received more than five home visits; and being active on December 2013 in low complexity I. The frequently mapped interventions were: education - disease process (98\%); nutritional counseling (98\%); environment control (95\%); and exercise promotion (94\%). The decline in the functional status of the program indicates that the guidelines were effective, but they are not standardized yet. It is recommended the adoption of a standardized language.

Descriptors: Aged; Nursing Care; Health Services for the Aged; Health Promotion; Nursing.

Objetivou-se analisar as intervenções de Enfermagem no prontuário de idosos assistidos no programa de gerenciamento de crônicos, comparando-as com a Classificação das Intervenções de Enfermagem. A investigação foi realizada em um Serviço Privado de Saúde do Rio de Janeiro, Brasil, em março de 2014. Estudo de mapeamento cruzado, com abordagem quantitativa. A amostra foi composta por 80 prontuários, segundo os critérios: atendido em 2013; média complexidade II; idade superior a 64 anos; ter tido mais de cinco visitas domiciliárias; e estar ativo em dezembro de 2013 em baixa complexidade I. As intervenções frequentemente mapeadas foram: ensino - processo da doença (98\%); aconselhamento nutricional (98\%); controle do ambiente (95\%) e promoção do exercício (94\%). 0 decréscimo do status funcional no programa indicou que as orientações foram efetivas, porém ainda não uniformizadas. Recomenda-se a adoção de uma linguagem padronizada.

Descritores: Idoso; Cuidados de Enfermagem; Serviços de Saúde para Idosos; Promoção da Saúde; Enfermagem.

El objetivo fue analizar las intervenciones de Enfermería en registros médicos de ancianos en atención en programa de gestión de pacientes crónicos, comparándolas con la Clasificación de las Intervenciones de Enfermería. Investigación llevada a cabo en servicio de salud privado del Rio de Janeiro, Brasil, en marzo del 2014. Estudio de mapeo cruzado, con enfoque cuantitativo. Muestra compuesta por 80 registros, según los siguientes criterios: asistidos en 2013; media complejidad II; edad mayor de 64 años; recibieron más de cinco visitas domiciliarias; y activos en diciembre del 2013 en baja complejidad I. Intervenciones frecuentemente mapeadas: educación - proceso de la enfermedad (98\%); asesoramiento nutricional (98\%); control del ambiente (95\%); y promoción del ejercicio (94\%). La disminución del estado funcional del programa indica que las directrices eran eficaces, pero aún no estandarizadas. Se recomienda adopción de lenguaje estandarizado.

Descriptores: Anciano; Atención de Enfermería; Servicios de Salud para Ancianos; Promoción de la Salud; Enfermería.

\footnotetext{
${ }^{1}$ Escola de Enfermagem Aurora de Afonso Costa, Universidade Federal Fluminense. Niterói, RJ, Brazil.

${ }^{2}$ Programa de Atenção Domiciliar à Saúde. Rio de Janeiro, RJ, Brazil.
}

Corresponding author: Rosimere Ferreira Santana

Rua Dr Celestino 74, Centro. CEP: 24020-091. Niterói, RJ, Brazil E-mail: rosifesa@enf.uff.br 


\section{Introduction}

It is estimated that in 2025, Brazil will occupy the sixth place in number of elderly people, reaching about 32 million people aged 60 or more. In 2050, children up to 14 years old will represent $13.15 \%$, while the elderly population will reach $22.71 \%$ of the total population. In 2010, mortality due to uncommunicable chronic diseases accounted for $73.9 \%$ of deaths, according to the Ministry of Health ${ }^{(1-2)}$.

Chronic conditions begin and evolve slowly. They usually have multiple causes, which vary over time, including heredity, lifestyle, exposure to environmental and physiological factors. These chronic conditions can lead to the loss of functional capacity and quality of life of the elderly ${ }^{(3-5)}$.

Most seniors carry organic diseases or disorders that generally should not be associated with activity limitation nor to their restriction of social participation. This is because even with chronic diseases, the elderly should continue to play their social roles. Thus, it is defended that the health focus of the elderly is closely related to the overall functioning of the individual, defined as the ability to manage his own life and take care of himself. That is, the elderly may be considered healthy when they are able to carry out their activities independently and autonomously, even in the presence of a health condition ${ }^{(6)}$.

According to the Law No. 8,080/90 it is guaranteed to the entire population, universal access to health services. However, according to the National Health Agency, in 2013, 25.1\% of the population was served by the private sector. In this scenario, health promotion activities should be expanded also in the private sector. In order to modify the hospital-centered care model, the National Health Agency determined the need to implement actions to encourage health care providers to be producers of care, attending people's health in full(7).

In 2005, the National Health Agency published the Normative Resolution No. 94 and the Normative Instruction No. 10, which established procedures for the presentation and criteria for the evaluation of programs of health promotion and disease prevention, which were proposed for companies of private health insurance of supplementary health assistance. However, only in August 2011, the Normative Resolutions 264 and 265 were published, which talk about the models of programs, the forms of monitoring and the possibility of offering prizes or discounts, as strategies to increase the participation of beneficiaries of the programs ${ }^{(7-8)}$. Thus, management of chronic patients and health promotion activities are recent in the supplementary health insurance area.

A pioneering example of implementation of chronic patients' care management in the private healthcare area happened in the United Kingdom. Customers from one of the largest health insurance companies, PruHealth, received financial benefits to leave their cars parked and walk, using a pedometer with a heart monitor. They also received discounts on the purchase of fruits and vegetables in a supermarket chain associated with the health care company, in addition to receiving financial incentive to practice physical exercises in gyms ${ }^{(9)}$. In short, a healthier lifestyle could lead to a reduction in their health contract's value $^{(10-11)}$.

Focus must be given to the work of nurses in these programs, indicated as responsible for the management of cases, for monitoring, for home visits and assistance phone calls ${ }^{(9-11)}$. To achieve this goal, the use of a standardized language can facilitate effective communication in relation to nursing phenomena. This is because the development of any science is related to the existence of an organized form of vocabulary ${ }^{(12) .}$

Nursing interventions are described in the Nursing Interventions Classification (NIC), developed by members of the Iowa Intervention Project, from the North American University of Iowa. This classification is organized currently under a taxonomic structure, with 7 domains, 30 classes, 542 nursing interventions and more than 12,000 activities/actions. The NIC facilitates the care process, clinical documentation, and 
information about the care provided. It can also be used at any level of care ${ }^{(13)}$.

Given the above, it was defined as a guiding question: What nursing interventions mapped in the records of the elderly who go to a chronic patient management program are described when compared to the Nursing Interventions Classification? The objective of the study was to analyze the nursing interventions from medical records of elderly people assisted in the chronic patient management program comparing them with the Nursing Interventions Classification.

\section{Method}

Study with quantitative, retrospective and observational approach, using methodological proposal of cross mapping. The cross mapping is defined as the process of explaining or expressing something through the use of words with the same or similar meaning. It allows one to map and compare nursing records made with non-standardized terminology in reference classifications with standardized language ${ }^{(14)}$.

The survey was conducted in a chronic management program that had 7,427 registered beneficiaries. Out of these, 5,219 were 65 years old or older. Medical records of elderly patients who improved their functional status in the period from January to December 2013 were selected to be analyzed in the study, adopting the following criteria: age $\geq 65$ years old; having received more than five visits; and being active on December 18, 2013, in low complexity I for more than 6 months. One excluded records with incomplete or inconsistent information. Following these criteria, it was obtained a final sample of 80 records.

The elderly are classified according to modules established by the coordination, taking into account the degree of complexity related to the risk factors such as smoking; alcoholism; number of visits to the emergency room and hospital admissions in the last year; family history; musculoskeletal, heart and lung impairment; decompensation of underlying diseases; sedentary lifestyle; number of comorbidities, among others.

The modules of attention to monitor the beneficiaries are defined as: average complexity I: those who receive monthly nursing home visits; medium complexity II: those with bi-monthly home visits; low complexity I for those who have semi-annual home visits; and low complexity II for seniors who receive annual home visits. It is highlighted that in all the modules of attention, the telephone monitoring is done monthly.

Thus, guidelines are provided through monthly telephone contact and home visits of the nursing team, according to the degree of complexity, aiming to prevent possible complications of chronic diseases such as hypertension, diabetes, lung diseases, among others, bringing improvement in the quality of life of people assisted and thus enabling the reduction of their healthcare costs.

Through this first thorough assessment, one defines the intervals at which patients must be assisted by the team. The modules are reviewed periodically by the nursing coordination, after the individual assessment of each electronic medical record, identifying the possibility of space or the need to reduce the monitoring interval, according to the health board.

The indicator used by the program coordination as a criterion to decrease complexity was the health status, related to a set of factors that showed improved health conditions, such as reduction of complications (hospitalization, passages in emergency rooms and visits in emergency services) for decompensation of underlying diseases; increased prevalence of physical activity; follow-up of the guidance provided; compliance of goals previously established; professional perception (visitor or monitor) that reported improved general health; comparative of tests results related to underlying diseases suggesting 
better health status; degree of independence for daily living activities; and adherence to the proposed therapy.

From the selected sample one conducted an individual evaluation of 80 records and analyzed the nursing guidance provided before the module change to low complexity I, ie, contributed in the functional changes of the elderly's status.

For data collection, one designed an electronic instrument of organization and processing of data divided into four parts: (1) demographic data of the patient; (2) status and functional characteristics of that classification; (3) terms that denoted non standardized nursing interventions; and (4) titles of nursing interventions found in the cross mapping. Data collection procedures were divided into four stages.

In the first stage, one collected demographic data of the existing electronic reports in the program, such as age, sex, educational level, marital status and even primary diagnosis, comorbidities and type of physician in order to define the profile of the population.

In the second stage, one applied the individual assessment to identify nursing guidance provided before the module change and recorded in the guidance field, both in business and in nursing telephone monitoring. Data were presented in a spreadsheet from Excel for Windows.

In the third stage, one carried out the mapping of nursing guidelines provided by the program and the interventions and activities that exist in the NIC. The fourth stage dealt with the analysis and comparison of the NIC Nursing intervention records regarding the following item: for each nursing orientation an intervention was selected in the standard system, based on the similarity between the item, the definition of the intervention and the activities suggested by it. Some program guidelines, however, were fragmented and fell into the same intervention, so they were grouped in the same NIC intervention. One mapped not only the words, but also their meaning. One maintained the consistency between the intervention that was being mapped and the definition of NIC intervention. One used the label of intervention more specific. Finally, the nursing guidelines that could not be mapped were described.

It is noteworthy that the ethical and legal aspects were attended, as recommended by the Resolution 466/12. The project was approved by the Research Ethics Committee of the College of Medicine/ University Hospital Antonio Pedro, under opinion number 241,194 in June 2013.

\section{Results}

Regarding the participants' profile, the predominant age group was 70-79 years old (55\%). Most were female (65\%), attended elementary school (78\%) and were married (56\%). Arterial hypertension $(86 \%)$ remained as the main medical diagnosis, followed by heart diseases (6\%) and non-insulin-dependent diabetes (6\%). Regarding the number of comorbidities, it was observed that $55 \%$ had four or more comorbid conditions, and $80 \%$ of the people assisted had the cardiologist as their main physician.

In Figures from 1-4, one describes 19 mapped nursing interventions distributed according to the domains of NIC: Physiological: Basic; Physiological: Complex; Behavioral and Security. The following domains were absent: Family; Health System and Community.

When evaluating nursing interventions provided by the program before the module change, for now defined in the medical records as nursing guidelines, one found 49 records, in a total of 80 files (Table 1). 


\begin{tabular}{|c|c|c|}
\hline Terms/Medical record & Intervention & Activities \\
\hline $\begin{array}{l}\text { Make } 3 \text { main meals } \\
\text { Eat every } 3 \text { hours }\end{array}$ & Nutritional advice & $\begin{array}{l}\text { Facilitate the identification of food behaviors to be modified; set realistic goals; } \\
\text { report on the health need for diet modification. }\end{array}$ \\
\hline Physical activity & Exercise promotion & $\begin{array}{l}\text { Report about the health benefits and physiological effects of exercise; guide } \\
\text { individuals on the right type of exercise for their health level. }\end{array}$ \\
\hline Kegel Exercise & $\begin{array}{l}\text { Exercises for the pelvic } \\
\text { muscles }\end{array}$ & Guide the elderly to perform muscle strengthening exercises of the pelvic region. \\
\hline Laxative diet & $\begin{array}{l}\text { Control constipation/ } \\
\text { impaction }\end{array}$ & $\begin{array}{l}\text { Monitor the signs and symptoms of constipation; advise on a diet with high fiber } \\
\text { content, as appropriate. }\end{array}$ \\
\hline Weight Loss & $\begin{array}{l}\text { Assistance to reduce } \\
\text { weight }\end{array}$ & $\begin{array}{l}\text { Determine the desire and individual motivation to lose weight; encourage the } \\
\text { replacement of undesirable habits for favorable habits; assist in the adaptation of } \\
\text { diets, to lifestyle and activity level of the patients }\end{array}$ \\
\hline
\end{tabular}

Figure 1 - Nursing interventions located in Physiological domain: Basic

\begin{tabular}{|l|l|l|}
\hline Terms/Medical record & \multicolumn{1}{|c|}{ Intervention } & \multicolumn{1}{c|}{ Activity } \\
\hline Increase fluid intake & Hydroelectrolytic control & $\begin{array}{l}\text { Promote oral intake; investigate in search of indications of altered electrolyte } \\
\text { balance. }\end{array}$ \\
\hline $\begin{array}{l}\text { Glycemic control } \\
\text { Record glucose levels }\end{array}$ & $\begin{array}{l}\text { Monitor blood glucose levels as indicated; monitor the signs and symptoms of } \\
\text { hyperglycemia; identify the possible cause of hyperglycemia; guide the patient/ } \\
\text { important people about the prevention, recognition and management of } \\
\text { hyperglycemia. }\end{array}$ \\
\hline
\end{tabular}

Figure 2 - Nursing Interventions located in the physiological domain: Complex

\begin{tabular}{|c|c|c|}
\hline Terms/Medical record & Intervention & Activity \\
\hline $\begin{array}{l}\text { Keep updated consultations } \\
\text { Keep updated exams } \\
\text { Indication to an expert }\end{array}$ & $\begin{array}{l}\text { Education: disease } \\
\text { process }\end{array}$ & $\begin{array}{l}\text { Measure the level of knowledge of patients; describe the signs and symptoms of the } \\
\text { disease; discuss changes in lifestyle that may be required; discuss treatment options; } \\
\text { strengthen the information given by other members of the healthcare team. }\end{array}$ \\
\hline $\begin{array}{l}\text { Follow prescription } \\
\text { Self-medication risks }\end{array}$ & $\begin{array}{l}\text { Education: drugs } \\
\text { prescription }\end{array}$ & $\begin{array}{l}\text { Inform the elderly about generic medications and brand-name ones; guide them about } \\
\text { the purpose and action of each drug; advise them about the correct administration; } \\
\text { the capability to self-administer the medication; give information about programs/ } \\
\text { organizations to save financial resources to obtain medicine and devices, as } \\
\text { appropriate. }\end{array}$ \\
\hline $\begin{array}{l}\text { Exercises to stimulate } \\
\text { memory }\end{array}$ & Memory training & $\begin{array}{l}\text { Discuss with the elderly/family all the practical problems experienced in relation to } \\
\text { memory; recall past experiences; implement memorization techniques such as visual } \\
\text { imagery, memory games, association techniques among others; guide new learning; } \\
\text { indicate to occupational therapy. }\end{array}$ \\
\hline
\end{tabular}

Figure 3 - Nursing interventions located in the domain: Behavioral

\begin{tabular}{|l|l|l|}
\hline Terms/medical record & \multicolumn{1}{|c|}{ Intervention } & \multicolumn{1}{|c|}{ Activity } \\
\hline $\begin{array}{l}\text { Risk of falling } \\
\text { Safe house }\end{array}$ & Environmental control & $\begin{array}{l}\text { Create a safe environment for the elderly; identify security requirements based } \\
\text { on the level of physical and cognitive functioning and previous behavioral history; } \\
\text { remove environmental hazards; educate the patient and family about the changes/ } \\
\text { precautions. }\end{array}$ \\
\hline $\begin{array}{l}\text { Blood pressure control } \\
\text { Record blood pressure }\end{array}$ & Monitoring of vital signs & $\begin{array}{l}\text { Watch trends and fluctuations in blood pressure; identify possible causes of changes } \\
\text { in vital signs. }\end{array}$ \\
\hline Immunization & $\begin{array}{l}\text { Control immunization/ } \\
\text { vaccination }\end{array}$ & $\begin{array}{l}\text { Report about immunizations that protect against diseases; notify individuals/ } \\
\text { families about the need to update vaccines. }\end{array}$ \\
\hline
\end{tabular}

Figure 4 - Nursing interventions located in the domain: Securitynça 
Table 1 - Main terms identified as nursing interventions in the medical records

\begin{tabular}{lc}
\hline Terms/nursing interventions & $\mathbf{n}(\mathbf{\%})$ \\
\hline Keep consultations updated & $78(97.5)$ \\
Balanced diet & $78(97.5)$ \\
Keep exams updated & $76(95.0)$ \\
Safe house & $76(95.0)$ \\
Physical activity & $75(93.7)$ \\
Increase fluid intake & $68(85.0)$ \\
Follow medical prescription & $64(80.0)$ \\
Risk of falling & $62(77.5)$ \\
Pressure control / record blood pressure levels & $60(75.0)$ \\
Directing to an expert & $49(61.2)$ \\
Leisure activity & $45(56.2)$ \\
Have three main meals & $35(43.7)$ \\
Raise legs & $34(42.5)$ \\
Eat every 3 hours & $33(41.2)$ \\
Glycemic control / record glucose levels & $26(32.5)$ \\
Kegel Exercise & $23(28.7)$ \\
Adequate sun exposure & $22(27.5)$ \\
Moisturize the skin & $20(25.0)$ \\
Self-medication risks & $17(21.2)$ \\
Lmmunization & $15(18.7)$ \\
Wtart prescribed physiotherapy & $12(15.0)$ \\
Exeight Loss & $12(15.0)$ \\
\hline
\end{tabular}

\section{Discussion}

It was found that $65 \%$ of participants were females, which may reflect the greater adherence of women to health prevention services or evidence the profile of the elderly population in Brazil. Thus, a different approach to male elderly patients is necessary for inclusion in the chronic management programs. One demonstrates the importance of their participation in the prevention of injuries to their health and for an improved quality of life, since the mortality and morbidity in this group would be higher compared with females ${ }^{(15)}$.
Another interesting finding was that $78 \%$ of the participants had studied up to the fifth grade (elementary school), which differs from the country's illiteracy rates. According to the National Survey of Households 2011, the illiteracy rate in the country was higher in older age groups. Most illiterate people (8.2 million; $96.1 \%$ of them) remained among people over 50 years old or older. However, the education of the participants can be connected to the fact that they are older people who have a health insurance, reflecting better financial conditions, which is closely linked to the level of education and to a greater accessibility to health services ${ }^{(15)}$.

One emphasized the importance of guidelines aimed at the risk factors connected to behaviors and lifestyles in relation to chronic conditions such as poor diet, being overweight, physical inactivity, excessive use of alcohol and smoking. It is known that, concerning the treatment of hypertension, the adoption of a healthy lifestyle with proper nutrition and physical activity, it is important and justifies the occurrence of these guidelines. The blood pressure control stands out for allowing one to monitor the effectiveness of the adopted therapy and to identify hypertensive crisis not associated with symptoms.

Another intervention that stood out was the encouragement of physical activity and, consequently, the maintenance of functional capacity of the elderly, one of the factors that contribute to an improved quality of life. In this sense, physical activity is a means to achieve independence and autonomy, and should be encouraged throughout life. One observed a reduction in the risk of premature death, heart disease, stroke, colon and breast cancer and type II diabetes in individuals who perform regular physical activities. In addition, the practice of exercises prevents the reduction of blood pressure, prevents weight gain, reduces the risk of obesity, helps prevent or reduce osteoporosis, promotes well-being and reduces stress, anxiety and depression $^{(16)}$.

The nursing interventions were also aimed at the demands of the private health insurance - first, to 
the treatment adherence, to operate together with the attending physician in health actions and, above all, the rational encouragement of health care resources.

The impact of the non-adherence to the treatment among elderly people and the prevalence of chronic diseases in this age group require treatments that require a high consumption of drugs, as well as changes in behavior and lifestyle habits. This can hinder the adhesion, leading to problems related to drugs, to a low control of the symptoms and to the reduction in the functional capacity ${ }^{(16)}$. And the higher the treatment compliance is, the better the results obtained are, being communication a useful tool between the health professional and the patient, to identify not only the non-adhesion but also the reasons. Thus, it was observed that the encouragement of adherence to the treatment is crucial. The elderly start to observe the improvement of their chronic condition, understand better their conditions, have more autonomy and feel increasingly motivated by the necessary changes in lifestyle.

Reducing the risk of falling reinforces a major concern for the elderly. The fall leads to the possibility of fracture, hospitalization and reduced functional capacity. About $30 \%$ of people aged 65 and over fall at least once a year. Among these people who fall, $40 \%$ are between 80 and 85 years old ${ }^{(17)}$. One emphasizes the specificity of the interventions to obese and sedentary individuals, since they are more likely to fall. However, it is emphasized that these are modifiable risk factors, so the adoption of physical and daily activities programs and guidance about environmental risks are necessary ${ }^{(18)}$.

A low fluid intake calls the attention of nurses because of the risk of dehydration; so there is its reinforcement during care management. The sensation of reduced thirst and the use of drugs that induce the increased urine volume and decreased renal function and urinary incontinence, increase the risk of dehydration ${ }^{(19)}$.

Leisure activities are very important, because in addition to promoting socialization, interaction and well-being, it stimulates cognitive skills. The prevention of functional loss should include adequate control of chronic diseases such as hypertension, asthma and diabetes, as well as stimulate cognitive activity. Work and leisure activities should be valued for their protective effect, as well as relationships with friends ${ }^{(20)}$. Therefore, they should be included in the list of suggested interventions for the domain health promotion in the NIC.

The nursing interventions found in the medical records were based on individual knowledge and on the nurses' experience about the chronic management program, which was the setting of this study. When analyzing the cross mapping, one verifies the suitability of the standardization of interventions record using the NIC. Thus, it is directed to the adoption of a formal language, which can particularize interventions and promote a trustworthy record of the guidelines.

\section{Conclusion}

Nursing guidelines provided by the chronic management program reflect the demand of the elderly by promoting adherence to the treatment, encouraging the adoption of healthy lifestyles and reduction of health care costs charged by health insurance companies, due to the reduction of the complications of chronic diseases, such as unnecessary hospitalizations. One can say therefore that they are crucial to ensure an active aging and maintain functional capacity.

The methodological limitation of cross-mapping was providing data collected retrospectively and by different professionals. The reliability and validity of the data were given due to the characteristics of the study place with professionals trained systematically, and with electronic medical records, which facilitated the data collection.

However, the interventions provided were not guided by a formal language system. From the data, it was considered feasible to fit it into a standardized language. When comparing the interventions made by the program, interventions and activities from the 
Nursing Interventions Classification, one reinforces the need for a standardized language and a qualifier instrument of care, which should facilitate the development of research and contribute to the performance in clinical practice.

\section{Collaborations}

Santana RF and Silva TN contributed to the project design and to the planning, analysis and interpretation of data, drafting and preparation of the article and final approval of the version to be published. Santos GLA, Silva LF, Bastos GM and Garcia TD contributed to the project design, analysis and interpretation of data and writing of the article.

\section{References}

1. Veras R. Envelhecimento populacional contemporâneo: demandas, desafios e inovações. Rev Saúde Pública. 2009; 43(3):548-54.

2. Instituto Brasileiro de Geografia e Estatística. Censo 2010 [Internet]. 2010 [citado 2014 dez 15]. Disponível em: http://censo2010.ibge.gov.br

3. Lorig K, Holman HR, Sobel D, Laurent D, González $\mathrm{V}$, Minor M. Living a healthy life with chronic condition: self-management of heart disease, arthritis, diabetes, asthma, bronchitis, enphysema and others. Boulder: Bull Publishing Company; 2006.

4. Hammerschmidt KSA, Ávila JBG, Santos SSC. Princípios básicos de geriatria e gerontologia. Ciênc Saúde Coletiva. 2010; 15(6):2997-8.

5. Kanso S, Romero DE, Leite IC, Marques A. A evitabilidade de óbitos entre idosos em São Paulo, Brasil: análise das principais causas de morte. Cad Saúde Pública. 2013; 29(4):735-48.

6. Instituto Brasileiro de Geografia e Estatística. Esperanças de vida ao nascer [Internet]. 2014 [citado 2015 jan 15]. Disponível em: http://brasilemsintese.ibge.gov.br/populacao/esperancas-de-vida-ao-nascer
7. Agência Nacional de Saúde Suplementar. Resolução Normativa no 265, de 19 de agosto de 2011 [Internet]. 2011 [citado 2014 out 23]. Disponível em: http://www.ans.gov.br/index2. php?option $=$ com_legislacao\&task=TextoLei\&format=raw\&id $=1796$

8. Agência Nacional de Saúde Suplementar. Manual técnico para promoção da saúde e prevenção de riscos e doenças na saúde suplementar. Rio de Janeiro: ANS; 2011.

9. Veras RP. Experiências e tendências internacionais de modelos de cuidado para com o idoso. Ciênc Saúde Coletiva. 2012; 17(1):231-8.

10. Veras RP. Prevenção de doenças em idosos: os equívocos dos atuais modelos. Cad Saúde Pública. 2012; 28(10):1834-40.

11. Araújo LF, Coelho CG, Mendonça ET, Vaz AVM, Siqueira-Batista R, Cotta RMM. Evidências da contribuição dos programas de assistência ao idoso na promoção do envelhecimento saudável no Brasil. Rev Panam Salud Publica. 2011; 30(1):80-6.

12. Campos EC, Cruz DALM, Herdman TH. Contribuição das linguagens padronizadas para a produção do conhecimento, raciocínio clínico e prática clínica da Enfermagem. Rev Bras Enferm. 2013; 66(spe):134-41.

13. Dochterman JM, Bulechek GM. Classificação das Intervenções de Enfermagem (NIC). $4^{\mathrm{a}}$ ed. Porto Alegre: Artmed; 2008.

14. Chianca TCM, Salgado PO, Albuquerque JP, Campos CC, Tannure MC, Ercole FF. Mapping nursing goals of an Intensive Care Unit to the Nursing Outcomes Classification. Rev Latino-Am Enfermagem. 2012; 20(5):854-62.

15. Instituto Brasileiro de Geografia e Estatística. Pesquisa nacional por amostra de domicílios: síntese de indicadores 2012 [Internet]. 2013 [citado 2015 jan 15]. Disponível em: ftp:// ftp.ibge.gov.br/Trabalho_e_Rendimento/ Pesquisa_Nacional_por_Amostra_de_Domicilios_ anual/2012/Sintese_Indicadores/sintese_ pnad2012.pdf 
16. Maciel MG. Atividade física e funcionalidade do idoso. Motriz Rev Educ Fis. 2010; 16(4):1024-32.

17. Perracini MR, Ramos LR. Fatores associados a quedas em uma coorte de idosos residentes na comunidade. Rev Saúde Pública. 2012; 36(6):70916.

18. Lima DWC, Cruz AMM, Morais FMP, Torres ADM, Freitas MC. Impact of a fall in the elderly: an analysis of the risk factors. Rev Rene. 2013; 14(5):929-37.
19. Siqueira FV, Facchini LA, Silveira DS, Piccini RX, Tomasi E, Thumé E, et al. Repercussão de quedas em idosos: análise dos fatores de risco. Cad Saúde Pública. 2011; 27(9):1819-26.

20. D'Orsi E, Xavier AJ, Ramos LR. Trabalho, suporte social e lazer protegem idosos da perda funcional: estudo epidoso. Rev Saúde Pública. 2011; 45(4):685-92. 